\title{
WestVirginiaUniversity.
}

Department of Economics

Working Paper Series

\section{Do Tourists Tip More Than Local Consumers? Evidence of Taxi Rides in New York City}

Amir B. Ferreira Neto

Adam Nowak

Amanda Ross

Working Paper No. 17-14

This paper can be found at the College of Business and Economics Working Paper Series homepage: 


\title{
Do tourists tip more than local consumers? Evidence of taxi rides in New York City
}

\author{
Amir Borges Ferreira Neto \\ West Virginia University \\ College of Business and Economics \\ Morgantown, WV 26506-6025 \\ em: amneto@mix.wvu.edu \\ Adam Nowak \\ West Virginia University \\ College of Business and Economics \\ Morgantown, WV 26506-6025 \\ em: adam.nowak@mail.wvu.edu \\ Amanda Ross \\ University of Alabama \\ Department of Economics, Finance, and Legal Studies \\ Culverhouse College of Commerce \\ Tuscaloosa, AL 35487-0224 \\ em: aross@cba.ua.edu
}

\begin{abstract}
We revisit the mechanisms that drive tipping behavior by comparing tourists and locals in New York City. It is unlikely a tourist will tip as a way of enforcing repeated interactions since they are not from the area, while a local may tip as an enforcement mechanism. However, if people tip because of social norms, we should see both tourists and locals tipping similar amounts. We compare locals and tourists who are theatergoers to control for education and income, as these factors are likely to affect tipping behavior. Using data from the New York City and Limousine Commission on yellow taxis, we identify tourists as those trips leaving from or going to a hotel and theatergoers as trips where the drop off or pick up is near Broadway within 30 minutes of the beginning or end of a show. Our results suggest that tourists and theatergoers tip more than locals and non-theatergoers, and tourists who are theatergoers tip even more, between $0.51 \%$ and $0.67 \%$ more. These results are robust across specifications and suggest that social norms are likely driving tipping behavior.
\end{abstract}




\section{Introduction}

Tipping is an important component of many service based industries. Azar (2003) estimates that tipping generates $\$ 27$ billion a year in the restaurant industry alone. While tipping is an important part of the service industry and the overall economy, there are still questions about the mechanisms that drive people to tip and how much they choose to tip. Azar (2003) p.1084 argues that "people tip because this is the social norm and disobeying the norm results in psychological disutility." ${ }^{1}$ Azar (2005) further examines various reasons why people tip and tries to explain what causes this behavior. First, he argues against the common belief that people tip as a monitoring process. In other words, he argues that people do not tip as a manner of "overseeing” the worker's performance on the job. Azar does argue that tipping is also more common for lower-wage occupations when there is a close relationship established between the customer and worker, as it would with a country club member and a golf caddy. Finally, he argues that tipping is more likely for occupations that provide the most psychological utility for consumers. ${ }^{2}$ Thus, we expect that for occupations like a waiter or a barber tipping will emerge; as customers develop a relationship with the worker and, due to the income difference, leaving a tip generates utility for the customer.

In this paper, we look at the differences in tipping between tourists and locals in the taxi industry in NYC. Tourists are unlikely to have repeated interactions with service workers. While statistically speaking local customers are unlikely to see the same cab driver twice, they may believe they will. Even if the locals know it is unlikely they will ever see a given cab driver

\footnotetext{
${ }^{1}$ Ben-Zion and Karni (1977) are the first authors to look into the social norm of tipping through an economic lens. Azar (2004a) provided a formal model corroborating the argument that people tip because it is a social norm. Greenberg (2014) looked at tipping in restaurants during the holiday season and found evidence that tipping is likely due to some intrinsic motive.

${ }^{2}$ For further information on tipping, Azar (2004b) provides an extensive review of the literature on the beginning of tipping norms and the literature that have addressed this issue thus far, and Azar (2007) reviews the literature on tipping in restaurants specifically.
} 
again, they may want to encourage good drivers to stay in the market and bad drivers to leave, and therefore tip to help this outcome occur. Any social norms regarding tipping behavior, however, are likely to affect both groups. ${ }^{3}$ To conduct our analysis, we draw upon a relatively novel dataset of all cab rides in NYC obtained from the New York City Taxi and Limousine Commission (TLC). Given the detail we have on the cab ride, we are able to infer local residents versus tourists based on where people are picked up or dropped off and analyze differences in tipping between the two groups.

Thus far, the majority of research on tipping has focused on restaurants. However, the taxi industry is a large portion of the service industry where tipping is of interest to researchers as well. ${ }^{4}$ TLC (2015) reports there are over 13,000 cabs in the city, with more than 50,000 drivers servicing 600,000 passengers a day (236 million passengers a year). ${ }^{5}$ Some existing research has examined tipping in the taxi industry. Haggag and Paci (2014) provide evidence that the default suggestions given in some taxis (i.e. 20\%, 25\%, or 30\%) when paying with credit cards have a positive impact on the amount tipped. Others have looked at how tipping affects the allocation of cabs throughout the city. For instance, Flath (2012) argues that if the amount of tipping corresponds to the Lindahl pricing of vacant cabs, then it is easier for regulators to improve the cab allocation by setting the cab fare to the marginal cost of the occupied taxis.

To determine the mechanisms that affect tipping, we examine differences in the tip amounts of local residents versus tourists. However, there are likely to be unobservable

\footnotetext{
${ }^{3}$ While in the U.S. this social norm argument is likely to be present and important, in other countries tipping is not as common of a practice. As a robustness check, we attempt to separate American versus international tourists to address concerns that there may be cultural differences driving tipping behavior.

${ }^{4}$ Ayres et al. (2005) looked at discrimination with regards to tipping taxi drivers using data from Connecticut.

5 TLC (2015) explains that the most common model of operation is the fleet model, in which a garage owns and operates the taxis while drivers lease the cab. In this system, there is the requirement of two shifts a day per taxi. Other possible models are an individual owner/operator vehicle and driver-owned vehicle. In the former the individual owns and operate the taxi while in the latter the owner of the taxi leases it to other drivers to operate.
} 
differences between locals and tourists that we cannot fully control for with our data. For example, tourists tend to have higher incomes and therefore we may observe higher tips because of an income effect. While our data has detailed information on the cab ride, such as where the individual was picked up, dropped off, the time of pick up and drop off, how much the ride cost, and how much the individual tipped, we do not know anything about the attributes of the passenger. Therefore, if we looked at all trips, there are likely to be many unobservable variables present. To address these concerns and to find comparable individuals, we focus on theatergoing individuals who are traveling to or from Broadway within 30 minutes of the start or finish of the show. ${ }^{6}$ By focusing on Broadway, we are able to implicitly control for various socioeconomic attributes that may affect tipping behavior. As pointed out by Seaman (2006), consumers of the performing arts tend to be more educated and have higher incomes. Therefore, by looking at only individuals who are coming to/from the Broadway district near show times, we are able to infer more about the socioeconomic attributes of the passengers and better control for unobserved attributes, such as income and education.

To test if tourists tip differently than locals, we need to determine if the passenger is a tourist. Using the TLC data, we assume that an individual is a tourist if he/she is picked up or dropped off at a hotel location. ${ }^{7}$ While this measure may not be exact, we believe that it is strongly correlated with the attributes we are trying to measure. Any biases in our classification of individuals into tourists or theatergoers based on these criteria are unlikely to be correlated with tipping behavior, and therefore would not bias our estimates. ${ }^{8}$ In addition, since tipping may

\footnotetext{
${ }^{6}$ We define Broadway as the area between $6^{\text {th }}$ and $8^{\text {th }}$ Avenues and between 41 st and 54th Streets.

${ }^{7}$ Tourists are those who have their ride starting or finishing 0.05 miles from a hotel which were obtained at http://excitingny.com/ website.

${ }^{8}$ As a robustness test, we consider areas 0.05 and 0.10 miles from a hotel. We do not find any difference in tipping between individuals picked up in this area and those picked up anywhere else in the city, supporting our argument that those picked up near hotels are likely to be tourists.
} 
be related to the ride and mood of the passenger, we include controls for trip distance, number of passengers, average temperature, and snow accumulation.

We find that tourists tip more than locals and that theatergoers tip more than nontheatergoers. Tourists tip 0.03 to 0.05 percent more than passengers who come from other locations and theatergoers tip between 0.22 to 0.33 percent more than other passengers. Tourists who are also theatergoers have an aggregate tip differential of 0.61 to 0.67 percent from other passengers. Given that the average tip is $\$ 2.47$, our estimates suggest that, on average, tourists tip one tenth of a cent $(0.1$ cent) more than non-tourists, theatergoers tip 0.8 cents more than nontheatergoers, and tourists who are theatergoers tip 1.65 cents more. While these numbers are small, recall that this is only for a selected portion of cab rides, and that these differences accumulate over time. For example, the TLC reports that there are 485,000 trips a day, with each shift lasting around 8 to 9.5 hours, and that there are approximately 13,500 medallions. Assuming all taxi drivers work the same length shift, this suggests each driver has approximately 9 to 10 rides a day and 3,600 passengers a year. Thus, this increase in tip amount from tourists who are theatergoers represents an additional 16 cents per day or $\$ 59.40$ per year for taxi drivers.

Our results are important for several reasons. First, by identifying two groups - tourists and locals - we are able to separate different mechanisms that could drive individuals to tip. While locals may tip as a way to encourage good drivers to stay in the market, tourists are unlikely to have the same incentives. Because we find that tourists tip more than locals, this suggests that it is more likely that it is a social norm that drives people to tip. Furthermore, as mentioned earlier, the higher tips from tourists may change the 'locus' of taxis in NYC if drivers learn and respond. This is important in terms of a locational equilibrium, and locals and/or policy makers may want to make adjustments to reach the ideal distribution of taxis. 
The remainder of the paper is as follows: section 2 provides a conceptual model and discusses various reasons why people may tip; section 3 describes the data used and the econometric model; section 4 presents and discusses our results; section 5 concludes and discusses the policy implications of our research.

\section{Conceptual Model and Motivations for Tipping}

We propose the following conceptual model, based off previous models developed by Parret (2006) and Conlin et al. (2003). A consumer $i$ maximizes his/her utility $\left(U_{i}\right)$ after riding in a taxi by choosing how much, in percentage of the total amount, he/she is going to tip for that ride $\left(T_{i}\right)$. We represent his/her utility function as:

$$
\max _{T_{i}} U_{i}=-p T_{i}+\gamma_{i}\left(T_{i}-\psi_{i}\left(t_{i}^{0}, s\right) \mid \alpha_{i}\right)
$$

Consumer i's utility function captures the trade-off between paying the tip and the utility gained by tipping and conforming to the norm. The first term, $p T_{i}$, is the monetary disutility from leaving a tip, where $p$ is the price of the ride. The second term, $\gamma_{i}\left(T_{i}-\psi_{i}\left(t_{i}^{0}, s\right) \mid \alpha_{i}\right)$, is the utility a consumer receives from tipping. The function $\psi_{i}$ is the service-adjusted tip norm that depends on the initial tip belief $\left(t_{i}^{0}\right)$ and the quality of the service $(s)$. Note that $\gamma_{i}$ is dependent on $\alpha_{i}$, which indicates if a consumer is a tourist or local. Thus, the utility in tipping comes from both tipping itself and from some psychological utility obtained from complying to a social norm. If locals tip to keep good drivers in business, the service-adjusted tip should be lower than the initial belief (assuming the default tip percent is this initial belief). In the case of tourists, the norm-adherence term is dependent on the cultural background of the individual and willingness to conform to the customs of the local community. Therefore, we would not expect a priori that these two groups will derive the same utility from tipping. 
Like Parret (2006), we assume that the function $\gamma_{i}$ is increasing and concave in $\left(T_{i}-\psi_{i}\left(t_{i}^{0}, s\right) \mid \alpha_{i}\right)$ and that the function $\psi_{i}$ is increasing and separable. We also assume that the utility function is strictly concave. Thus, we obtain the following first and second order conditions from the utility maximization problem in Equation (1):

$$
\begin{aligned}
& \Lambda=\frac{\partial U_{i}}{\partial T_{i}}=-p+\gamma_{i}^{\prime}\left(T_{i}-\psi_{i}\left(t_{i}^{0}, s\right) \mid \alpha_{i}\right) \\
& \Pi=\frac{\partial \Lambda}{\partial T_{i}}=\gamma_{i}^{\prime \prime}\left(T_{i}-\psi_{i}\left(t_{i}^{0}, s\right) \mid \alpha_{i}\right)
\end{aligned}
$$

Because the utility function is strictly concave in tipping, we know that $\gamma_{i}^{\prime \prime}<0$. Therefore, we know that $\Pi<0$. Using the implicit function theorem, we can obtain the following comparative statics:

$$
\begin{aligned}
& \partial T_{i} / \partial s=-\left\{\gamma_{i}^{\prime \prime}\left(T_{i}-\psi_{i}\left(t_{i}^{0}, s\right) \mid \alpha_{i}\right)\left[\partial \psi_{i} / \partial s \mid \alpha_{i}\right] / \Pi\right\}>0 \\
& \partial T_{i} / \partial t_{i}^{0}=-\left\{\gamma_{i}^{\prime \prime}\left(T_{i}-\psi_{i}\left(t_{i}^{0}, s\right) \mid \alpha_{i}\right)\left[\partial \psi_{i} / \partial t_{i}^{0} \mid \alpha_{i}\right] / \Pi\right\}>0
\end{aligned}
$$

Although the expected sign for each of these partial derivatives is the same for locals and tourists, we are unable to make any claim about the magnitude of these partials. Therefore, as mentioned earlier this section, which effect is larger is theoretically ambiguous and it is an empirical question as to which group will tip more. Our empiric analysis will allow us to shed light on this issue and the possible mechanisms present regarding tipping behavior.

\section{Data and Econometric Model}

Data

To determine whether tourists tip more or less than local consumers, we use the New York City Taxi and Limousine Commission (TLC) dataset which contains detailed data on all taxis ride in NYC between January 2014 and July of 2015. Given the extremely large number of observations 
in this dataset, we restrict ourselves to a random $10 \%$ sample, containing 24,219,485 observations. The data set includes 6-digit latitude and longitude pick-up and drop-off locations, miles covered, how the passenger paid, time spent in the cab, number of passengers, fare amount, tip amount, and a breakdown of costs (i.e. tolls and any MTA taxes). The data is available for all of 2014 and half of $2015 .^{9}$ The dataset contains the population of all taxi rides during this time period.

To conduct our analysis, we must first identify which passengers are tourists and which are local consumers. As the TLC dataset provides the geocoded pick-up and drop-off location for each trip, we use this information in order to identify an individual as a tourist. Specifically, we assume that passengers who were either picked up or dropped off within 0.05 miles (approximately 264 feet) of a hotel are tourists. This cutoff is comparable to the length of an average block in NYC. As such, our cutoff reflects the notion that most tourists leaving a hotel will hail a cab within one block of the hotel. To determine where hotels are located, we used the http://excitingny.com/ website to obtain the location of the 363 listed hotels. To differentiate quality of the hotels, we use the Forbes classification and match the 4- and 5-star hotels to our list. We assume that any individuals who were not picked up or dropped off close to a hotel are not tourists. ${ }^{10}$

As mentioned earlier, there are many things that affect tipping behavior and while the TLC dataset has detailed information on the ride, it does not contain information on the passenger. Given that individual attributes are likely to affect tipping behavior, we restrict our

\footnotetext{
${ }^{9}$ This data can be downloaded at http://www.nyc.gov/

${ }^{10}$ We acknowledge that tourists may take cabs to get from one site to another that is not a hotel or the theater district. However, we do not believe this will bias our results due to of the time of the day restriction we make (roughly, between $7 \mathrm{pm}$ and $8 \mathrm{pm}$ and 9:30pm and 10:30pm). During this time, it is more likely that tourists are leaving the hotel to go to a show or returning to the hotel from a show. If we were using every hour of the day, this would more of a concern.
} 
sample so that we can proxy for many socioeconomic variables. In particular, we focus on individuals who are the most likely to be consumers of the performing arts. Seaman (2006) and Lévy-Garboua and Montmarquette (2003) conduct an extensive literature review on the demand for the arts and conclude that people who consume performing arts tend to be more educated and have higher incomes. Therefore, we focus on people who are going to or from the theater district as a way of implicitly controlling for these socioeconomic attributes. We define the theater district, or Broadway, as the area within the $6^{\text {th }}$ to $8^{\text {th }}$ Avenues, between 41 st and 54 th Streets. ${ }^{11}$ We focus on the performing arts because we are better able to identify theatergoers as there are clear start and end times for the shows, which is not true for art galleries or museums. We restrict our sample to cab rides that occur within 30 minutes before and after a show starts. To do this, we use the average starting and finishing time of a Broadway show, presented in Table $1 .^{12}$ By imposing this time constraint, we restrict our sample to individuals who are the most likely to be going to Broadway for a show compared to individuals who are going to the area for some other purpose.

Because shows occur all day Sundays and are not performed on Mondays, we exclude Sunday and Monday cab rides. According to the Broadway schedule, ${ }^{13}$ only 6 out of 23 shows are performed on Mondays while from Tuesday to Saturday at least 20 out of the 22 shows are performed each day. ${ }^{14}$ Because the tipping data are generated for credit card payments only and do not include cash tips, we restrict our sample to those individuals who paid by credit card. After making all these restrictions, our sample still includes more than 2 million observations.

\footnotetext{
${ }^{11}$ http://www.nyc.com/visitor_guide/theater_district.702514/editorial_review.aspx

${ }^{12}$ We obtain the list of shows and their schedule from the Broadway website.

${ }^{13} \mathrm{http}$ //www.playbill.com/article/weekly-schedule-of-current-broadway-shows-com-142774

14 Tuesday one show is dark and Wednesday 2 shows are dark. Sunday also has some shows that are dark, but this day is already excluded given that shows run throughout the day.
} 
Figure 1 presents the distribution of rides by hour for cab rides going to Broadway on Tuesday through. From Tuesday to Friday we observe a spike around 7pm (hour 19), especially on Fridays which we would expect to be the evening when the most individuals attend a show. There are fewer morning commutes on Saturday, but Saturday evening still displays a spike in taxi rides around 7pm when most shows begin.

Another factor that may influence tipping behavior is the mood of passenger, possibly due to weather conditions. For example, if it is raining, cab passengers may be overly appreciative because the individual was able to avoid walking in the rain and may tip more than he would on a sunny day. We obtain data for the average temperature, precipitation, and snow accumulation from National Oceanic and Atmospheric Administration (NOAA) and control for the effects of weather. Table 2 presents the descriptive statistics for all variables in our dataset ${ }^{15}$ and Appendix A1 provides a description and the source of each variable.

Before performing our econometric analysis, it is interesting to explore our sample with respect to our outcome variable, i.e. tip amount. To do so, we map the tipping patterns of locals and tourists to see if they are similar. Figures 2 and 3 show the tip amounts for locals and tourists, respectively; and Figures 4 and 5 show the tipping percent of the fare amount for locals and tourists, respectively. The four maps suggest that there are differences between local and tourists' behavior in tipping, as the hot spots of tipping vary between the two groups. More specifically, locals tip the most in the Midtown area, whereas tourists tip more in the southwest corner of the island and near Times Square. The tip percentage figures (4 and 5) show a different pattern. The tip percent hots spots for tourists are spread all over the city, possibly because hotels are spread around New York. As for locals, we notice three hot spots: one in the

\footnotetext{
${ }^{15}$ Appendix A1 provides a full description and the source of each of our variables.
} 
east of Central Park, one in Midtown and one in the Chelsea-Gramercy area. The Midtown area is known for business and the other two are known residential areas in the city.

\section{Econometric Model}

To estimate the effect of these characteristics on tip amount, we estimate the following model:

$$
\text { tip } \left._{i}=\beta_{0}+\beta_{1} \text { Tourist }_{i}+\beta_{2} \text { Theater }_{i}+\beta_{3} \text { (Tourist }_{i} * \text { Theater }_{i}\right)+X_{i} \delta+\varepsilon_{i}
$$

Where tip $_{i}$ is the tip amount paid on trip $i$. Tourist $t_{i}$ is an indicator variable equal to 1 if we classify the individual as a tourist. Theater $i$ is an indicator equal to one if we classify the individual as a theatergoer. We also include a variety of control variables, $X_{i}$, including trip distance, passenger count, if the passenger was dropped off within five minutes of the start of the show, average temperature, new snow fall, and snow depth. $\varepsilon_{i}$ is an idiosyncratic error term.

In this model, $\beta_{1}$ gives the difference in tip amount for tourists relative to all other passengers and $\beta_{2}$ is the difference in tip amount for theatergoers relative to other passengers. Our primary coefficient of interest, $\beta_{3}$, gives the relative difference in tip amount between tourists going to the theater district and all others. To further control for possible income differences of the passengers, we use the quality of the hotel as a proxy for the wealth and preferences of the customers that we classify as tourists. We include dummy variables if the passenger was coming from/going to a top hotel, i.e., a hotel rated a 4- or 5-star hotel by Forbes.

Initially, we estimate the above model using OLS. However, there are a lot of zeros present (approximately one third of passengers leave no tip) suggesting that the data may be truncated. To address this, we first employ a Tobit model to account for the censoring at zero as the observed zeros may be true zeros, i.e., they represent individuals who choose not to tip due to the level of service received. However, the Tobit model does not explicitly address a potential 
sample selection wherein individuals who chose not to tip may be different from individuals who do tip. ${ }^{16}$ To address this, we use the Heckman two-stage sample selection correction; the decision to tip is modeled in the first state and the conditional probability of tipping is used to control for potential sample selection in the second stage estimates. The Heckit model has been used many times in the previous literature to address this selection problem (see, for example, Heckman and Sedlacek, 1985; Badel and Peña, 2010; Winter et al, 2012; and Jiménez et al, 2014).

\section{Results}

Our main results are presented in Tables 3 to 6, and only show the variables of interest: whether the individual is a tourist, going to the theater district, and indicators for the quality of the hotel. ${ }^{17}$ First, we present our baseline OLS results in Table 3. Column (1) has no controls other than the indicators for hotel, theatergoer, and their interaction. Column (2) includes trip controls such as trip distance, number of passengers, and if the passenger was dropped off within 5 minutes of a show beginning. Column (3) includes the weather controls (average temperature, precipitation, new snow, and snow depth). Lastly, Column (4) differentiates high quality hotels, those with 4- or 5-stars on the Forbes website.

Looking across the four columns of Table 3, we see that the coefficients are similar across the specifications, though we have a higher $\mathrm{R}^{2}$ with the additional controls. Given that the coefficients are similar, we focus our discussion on Column (4) as this includes the most control variables. We see in Column (4) that tourists tip approximately 0.06 percent more than nontourists and that theatergoers tip 0.15 to 0.19 percent more than non-theatergoers, depending if

\footnotetext{
${ }^{16}$ For a more detailed discussion on the difference between the models see Humphreys (2015).

${ }^{17}$ Full results are available from the authors upon request.
} 
they are going to or coming back from the theater. Tourists who go to the theater tip even more, approximately 0.41 to 0.47 percent. Tourists at high end hotels tip more when they leave the hotel, but not when they return.

Our results corroborate the literature suggesting education and income are related to tipping. For example, Azar (2005) argues that tipping is created in occupations where the consumer can show gratitude or when there is a wage differential between the consumer and worker. Therefore, as theatergoers are likely to have higher education levels and higher incomes, we expect they will tip more than non-theatergoers. With regards to tourists, the results suggest not only that they incorporate social norms, but that they are willing to tip more than locals, which may suggest a higher level of gratitude or an increased willingness to spend when on vacation.

Results using a Tobit model are presented in Table 4. Looking at Table 4, we see that the coefficients have a similar pattern with regards to the sign of the effect and statistical significance. However, the estimated magnitude of the effect is higher than the OLS counterparts in Table 3, suggesting that the OLS estimates have a slight downward bias due to the zeros, consistent with our expectations.

However, as we can see from the distribution of tips shown in Figure 6, there is a significant gap in the distribution between those that tip zero and those that tip a positive amount. This type of distribution suggests that it is not so much censoring at zero that is the problem, but that there is a selection process between zero and positive values. Therefore, a selection model, such as a Heckit model, is likely to be the appropriate specification. The results for the Heckman 
selection model are presented in Table $5 .{ }^{18}$ As we see in Table 5, the results are similar in terms of the sign and significance levels of the coefficients to Tables 3 and 4 . Tourists tip between 0.03 and 0.05 percent more, theatergoers tip 0.22 to 0.33 percent more, and tourists who are theatergoers tip 0.61 to 0.67 percent more. Tourists in 4- and 5-star hotels tip 0.10 percent more, and again only when they are leaving the hotel. ${ }^{19}$

At first glance, the results above appear to be small in magnitude. However, when compared to the results of other determinants ${ }^{20}$ of tipping, such as number of passengers (0.045), trip distance $(-0.060)$ and weather (new snow: 0.051; avg. temp: -0.001 ), the above effects are similar in magnitude. Therefore, we can affirm that these differentials between tourists and locals are indeed important relative to other variables. Moreover, it is important to remember that our results are for credit card transactions only, and these effects may differ if cash payments are included.

\section{Falsification Test}

One concern with our results thus far is that the dummy variable identifying tourists is not identifying only tourists but rather anyone who happens to hail a cab near a hotel. In Table 6, we present a falsification test similar to Linden and Rokoff (2008). As previously discussed, we identified tourist as those who were picked up or dropped off within 0.05 miles of a hotel. Now, we identify a comparison group: those individuals picked up or dropped off between 0.05 and

\footnotetext{
${ }^{18}$ As an additional robustness check we used a double hurdle model. In this model, the observed zeros are true corner solutions. The results show the signs remain the same and they are still statistically significant. The results can be provided upon request.

${ }^{19}$ We have also estimated Probit and Logit models and the results follow the same pattern. These results are not shown in the interest of space, but are available from the authors upon request.

${ }^{20}$ The results in parenthesis are for the Heckman model for trip distance and weather and the Tobit model for the number of passengers.
} 
0.1 miles of a hotel. In other words, we are comparing those individuals who are picked up or dropped off on the immediately adjacent blocks to a hotel.

We believe that those individuals who are picked up or dropped off within 0.05 miles of a hotel are more likely to be tourists that those 0.05 to 0.1 miles from a hotel because they are closer to the hotel. However, if we are not picking up tourists but rather locals who happen to be near hotels then both groups should behave in a similar manner. In Table 6, we do not find a difference between pickups and drop offs slightly further away from the hotel from the rest of the city. This result provides additional support that we are capturing tourists versus locals using our identification scheme.

\section{Cultural Differences in Social Norms}

Because we do not have information on the passengers, it is not possible to control for differences in cultural norms which may be correlated with tipping behavior. Specifically, tipping tends to be an American custom, so one reason we may see differences in behavior is that there are cultural differences between the individuals we classify as locals versus tourists. To mitigate this problem, we randomly selected 100 hotels out of the 363 hotels in our list, and scraped hotel reviews using tripadvisor.com for the 2014 period. We use the language of the review in order to infer the native language of the reviewer and whether the individual is likely to be a domestic or international guest. We then split our sample into hotels with more international guests and hotels with more domestic guests. From the 100 hotels we obtained information from, we classified 32 hotels as having primarily international patrons and 68 as primarily domestic. 
Table 7 shows the results considering only the tourists for these 100 hotels and the nontourist passengers. Focusing on the Heckit model in Column (3), we see that tourists coming from hotels with more international guests going to the theater district, tip more than tourists coming from hotels with more domestic guests. When returning to the hotel, tourists returning to more domestic hotels tip more than tourists returning to more international hotels. Overall, we do not find systematic evidence that international customers are tipping less, suggesting that tourists are learning the local norms and adapting. ${ }^{21}$

\section{Conclusions and Policy Implications}

In this paper, we examined if there are differences in tipping behavior between locals and tourists. To accomplish this, we focus on New York City and use a novel dataset from the Taxi and Limousine Commission (TLC). Using geo-coordinates of the pick-up and drop-off locations, we identify which passengers are more likely to be tourists. Our analysis suggests that tourists tip more than locals and that theatergoers tip more than non-theatergoers. Specifically, the results show that tourists tip 0.03 to 0.05 percent more, theatergoers tip 0.22 to 0.33 percent more, and tourists who are theatergoers tip between 0.61 to 0.67 percent more. In monetary terms, tourists who are theatergoers would tip 1.66 cents more than a local, where the average tip is $\$ 2.47$ dollars. These results are consistent across several specifications, in which we control for possible sample selection and censoring.

There are three main policy implications of our analysis. First, because tourists tip more than locals, the impact of tourists on a local economy may be underestimated, as tips are frequently not reported income and therefore are not included when calculating multiplier effects

\footnotetext{
21 The log-likelihood ratio test comparing the specification with the split sample of hotels between domestic and international hotels versus a specification in which we do not make such split shows that the former is a preferred specification. This suggests our two hotels sample are different and we gain extra and useful information by splitting the sample.
} 
of tourism on the economy. Second, we find evidence that wealthier and more educated people tip more. This suggests that one way to attract such individuals to an area is to provide cultural amenities similar to those found on Broadway. Third, if the extra tip is sufficient to change the behavior of taxi drivers, these individuals might change their locus of work. This suggests that locals need to adopt to correct this change by taxis, or that policy makers may need to get involved to help correct this inefficiency.

Future research should focus on obtaining more information from both passengers and drivers, as well as information on cash tipping. One of the caveats of our analysis is that we only observe credit card tips. Therefore, the difference in tipping behavior we have observed may change once we account for those who pay or tip in cash. With better information on passengers and drivers, we would be able to tease out the determinants of tipping in a more comprehensive way. Also, information on cash tips would provide better measurement of behavior, since then we could control for the payment method which the previous literature (Lynn, 2006) has found influences tipping.

\section{References}

Alderighi, M. and Lorenzini, E. (2012). Cultural goods, cultivation of taste, satisfaction and increasing marginal utility during vacations. Journal of Cultural Economics, 36(1):1-26.

Arnott, R. (1996). Taxi travel should be subsidized. Journal of Urban Economics, 40(3):316-333.

Ayres, I., Vars, F. E., and Zakariya, N. (2005). To insure prejudice: Racial disparities in taxicab tipping. Yale Law Journal, 114. Available at SSRN: http://ssrn.com/abstract=401201. 
Azar, O. (2003). The implications of tipping for economics and management. International Journal of Social Economics, 30(10):1084 - 1094.

Azar, O. H. (2004a). The history of tipping from sixteenth-century England to United States in the 1910s. The Journal of Socio-Economics, 33(6):745 - 764.

Azar, O. H. (2004b). What sustains social norms and how they evolve?: The case of tipping. Journal of Economic Behavior \& Organization, 54(1):49 - 64.

Azar, O. H. (2005). Who do we tip and why? an empirical investigation. Applied Economics, 37:1871-1879.

Azar, O. H. (2007). The social norm of tipping: A review1. Journal of Applied Social Psychology, 37(2):380-402.

Badel, A. and Peña, X. (2010) Decomposing the Gender Wage Gap with Sample Selection Adjustment: Evidence from Colombia. Federal Reserve Bank of St. Louis, Working Paper 2010-045A.

Ben-Zion, U. and Karni, E. (1977). Tip payments and the quality of service, page 37-44. Essays in Labor Market Analysis. John Wiley \& Sons.

Castiglione, C. and Infante, D. (2015). Rational addiction and cultural goods: the case of the Italian theatregoer. Journal of Cultural Economics, pages 1-28.

Census (2016). http://www.census.gov/quickfacts/table/SEX205210/3651000

Conlin, M., Lynn, M., and O’Donoghue, T. (2003). The norm of restaurant tipping. Journal of Economic Behavior and Organization, 52(3): 297-321.

Flath, D. (2012). Why do we tip taxicab drivers? Japanese Economy, 39(3):69-76. 
Greenberg, A.E. (2014). On the complementarity of prosocial norms: The case of restaurant tipping during the holidays. Journal of Economic Behavior and Organization.97, pp. 103-112.

Haggag, K. and Paci, G. (2014). Default tips. American Economic Journal: Applied Economics, 6(3):1-19.

Heckman, J. and Sedlacek, G. (1985) Heterogeneity, Aggregation and Market Wage Functions: An Empirical Model of Self-Selection in the Labor Market. Journal of Political Economy, 93(6):1077-1125.

Humphreys, B. (2015) Dealing with Zeros in Economic Data: Theory and Application to Participation in Leisure Time Physical Activity. Mimeo.

Kim, H., Cheng, C-H. and O’Leary, J. T. (2007) Understanding participation patterns and trends in tourism cultural attractions. Tourism Management, 28:1366-1371.

Jiménez, G., Ongena, S., Peydró, J.-L. and Saurina, J. (2014) Hazardous Times For Monetary Policy: What Do Twenty-Three Million Bank Loans Say About The Effects Of Monetary Policy O N Credit Risk-Taking? Econometrica, 82(2):463-505.

Lévy-Garboua, L. and Montmarquette, C. (2003). Demand, chapter 25, pages 201- 213. Handbook of Cultural Economics. Edward Elgar.

Linden, L. and Rockoff, J. E. (2008) Estimates of the Impact of Crime Risk on Property Values from Megan’s Laws. American Economic Review, 98(3):1103-1127

Lynn, W. M. (2006) Tipping in Restaurants and Around the Globe: An Interdisciplinary Review. Handbook of Contemporary Behavioral Economics, chapter 31, pages 626-646, Routledge. 
Mohring, H. (1972) Optimization and Scale Economies in Urban Bus Transportation, American Economic Review, 62(4): 591-604.

New York City Taxi and Limousine Commission (2015)

http://www.nyc.gov/html/tlc/downloads/pdf/2014_taxicab_fact_

Parrett, M. (2006) An Analysis of the Determinants of Tipping Behavior: A Laboratory Experiment and Evidence from Restaurant Tipping. Southern Economic Journal, 73(2):489-514.

Seaman, B. A. (2006). Empirical Studies of Demand for the Performing Arts, volume 1 of Handbook of the Economics of Art and Culture, chapter 37, pages 415-472. Elsevier.

Throsby, D. (2003). Cultural Capital, chapter 19, pages 166-169. Handbook of Cultural Economics. Edward Elgar.

Wessels, W. (1997). Minimum wages and tipped servers. Economic Inquiry, 35:334-349.

Winters, M. A., Dixon B. L. and Greene, J. P. (2012) Observed characteristics and teacher quality: Impacts of sample selection on a value added model. Economics of Education Review, 31:19-32 
Figure 1: Trips Going to Theater District by 15 Minute Interval

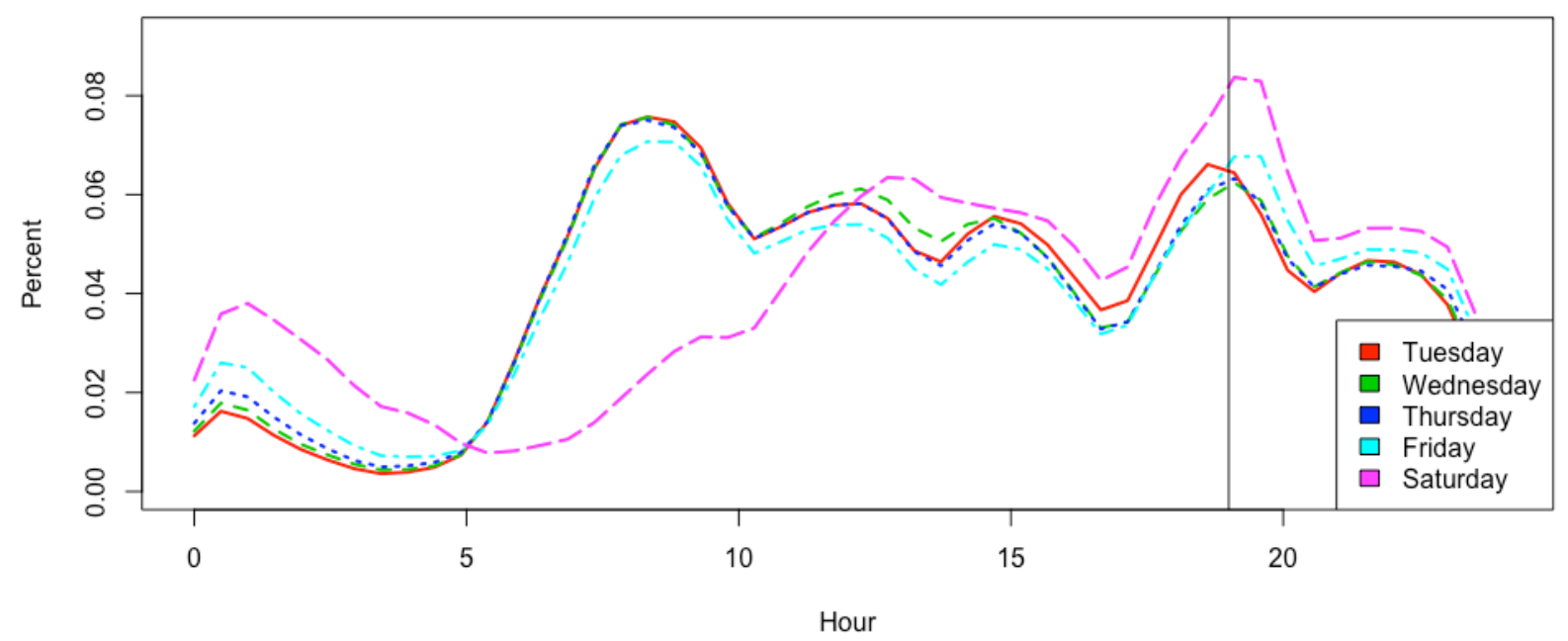

Figure 2 - Tipping amount pattern of locals

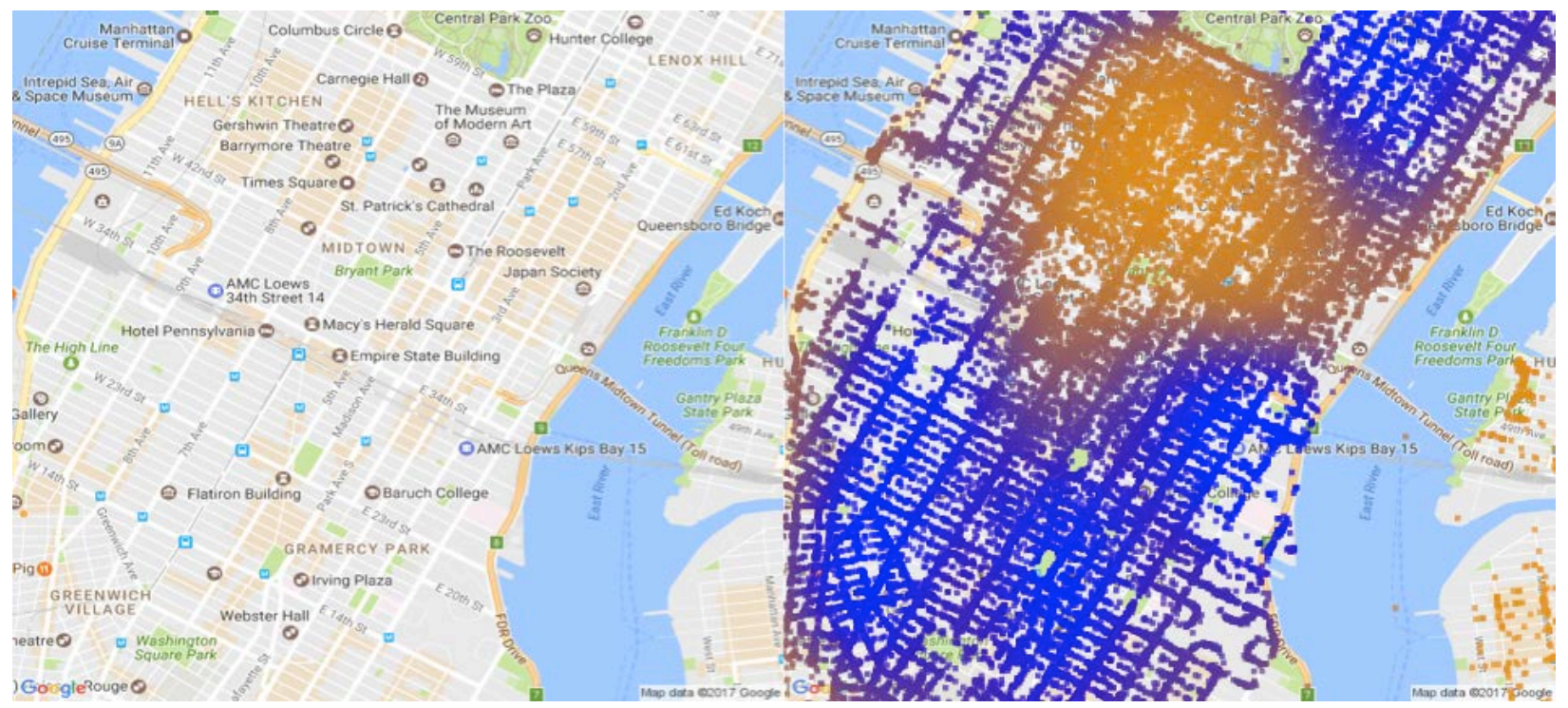

Note: The scale goes from blue to orange. Areas with higher concentration of orange means the higher the tip amount paid. 
Figure 3 - Tipping amount pattern of tourist

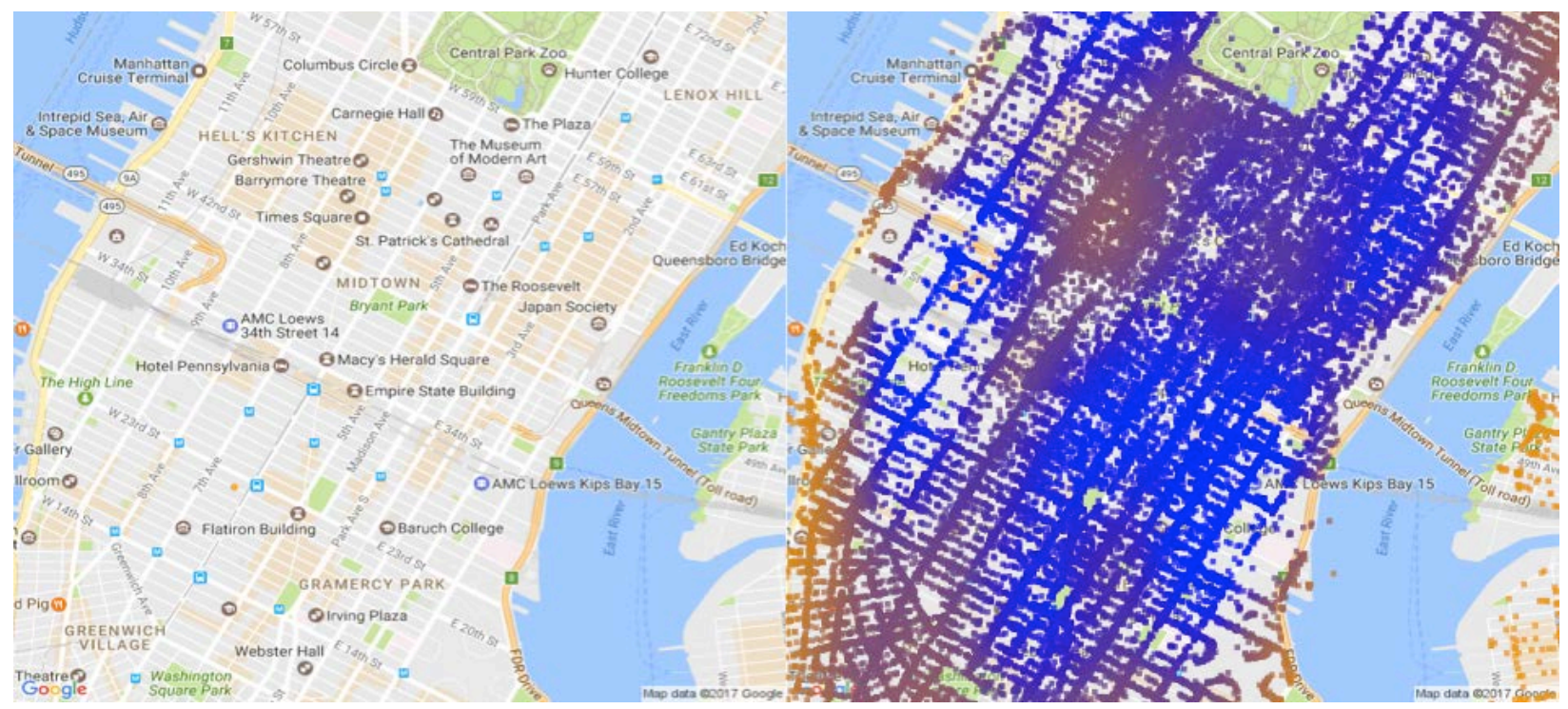

Note: The scale goes from blue to orange. Areas with higher concentration of orange means the higher the tip amount paid.

Figure 4 - Tipping percent pattern of locals

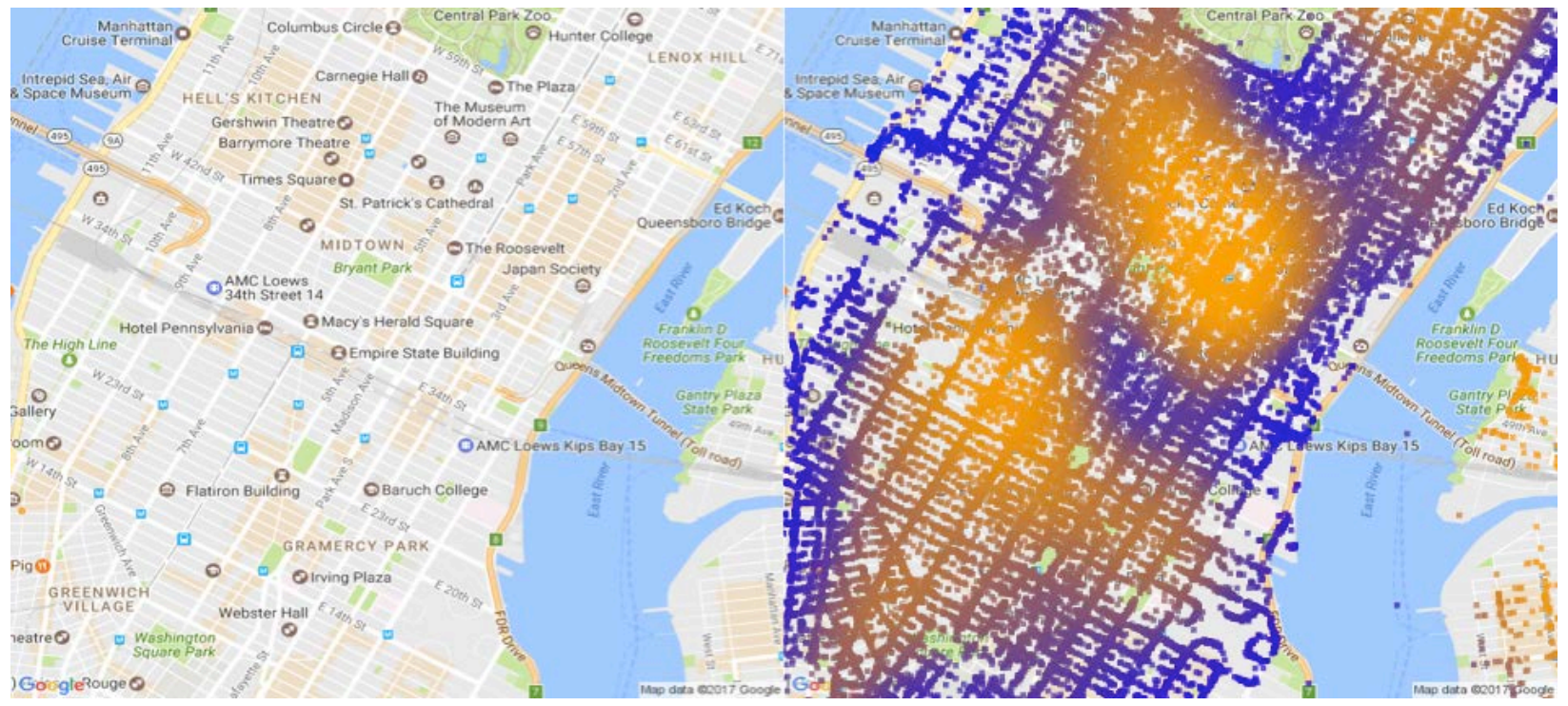

Note: The scale goes from blue to orange. Areas with higher concentration of orange means the higher the tip percent paid. 
Figure 5 - Tipping percent pattern of tourist

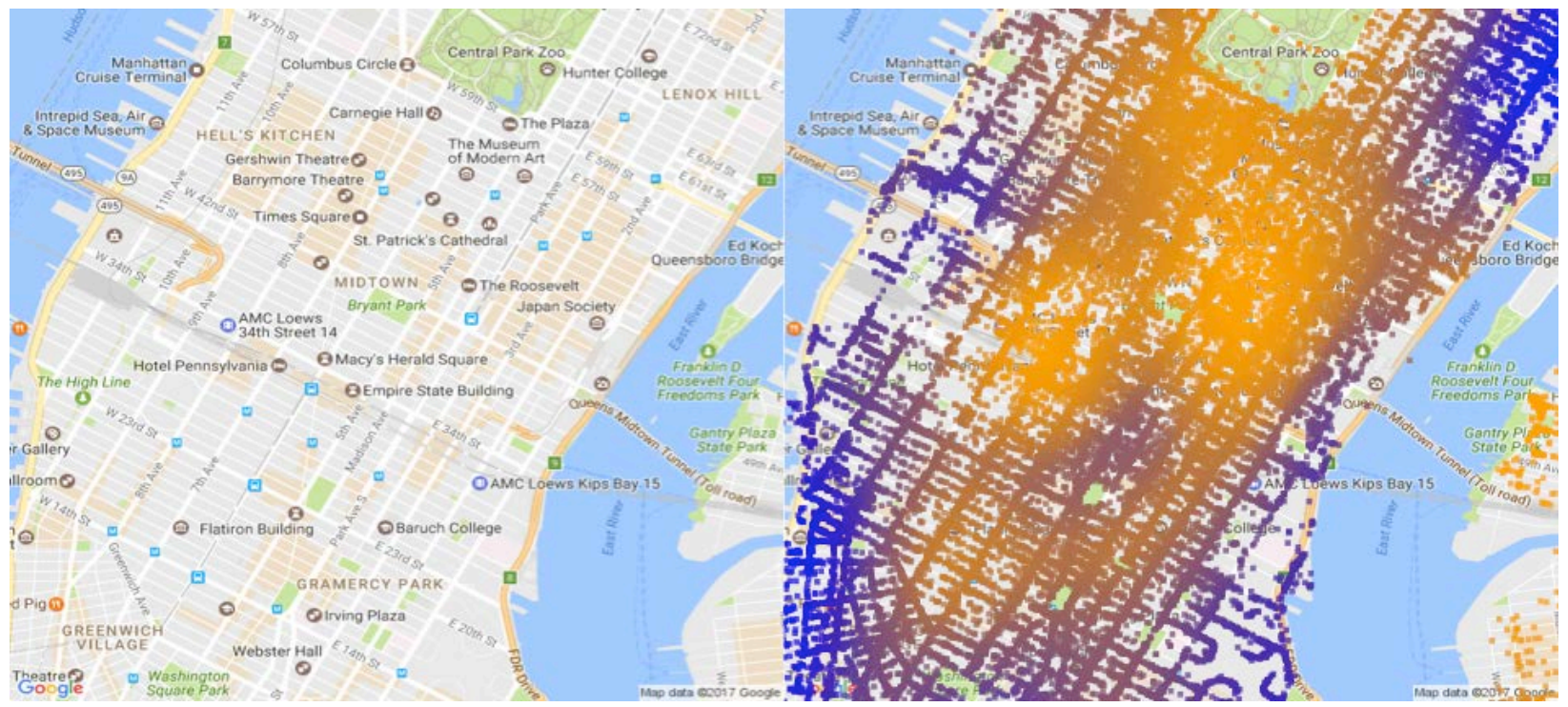

Note: The scale goes from blue to orange. Areas with higher concentration of orange means the higher the tip percent paid.

Figure 6 - Histogram of tip percentage

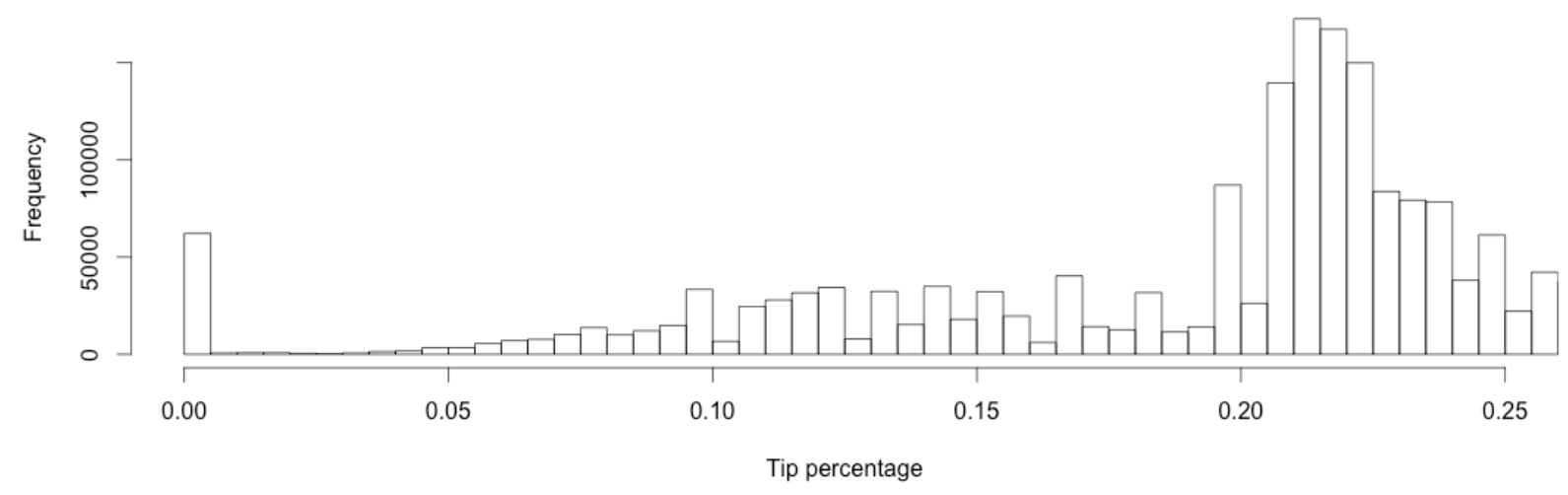


Table 1 - Day and Time of Broadway Shows

\begin{tabular}{ccc}
\hline Weekday & Starting Time & Ending Time \\
\hline Tuesday & $19 \mathrm{~h} 30 / 07: 30 \mathrm{pm}$ & $22 \mathrm{~h} 00 / 10: 00 \mathrm{pm}$ \\
Wednesday & $20 \mathrm{~h} 00 / 08: 00 \mathrm{pm}$ & $22 \mathrm{~h} 00 / 10: 30 \mathrm{pm}$ \\
Thursday & $19 \mathrm{~h} 30 / 07: 30 \mathrm{pm}$ & $22 \mathrm{~h} 00 / 10: 00 \mathrm{pm}$ \\
Friday & $20 \mathrm{~h} 00 / 08: 00 \mathrm{pm}$ & $22 \mathrm{~h} 00 / 10: 30 \mathrm{pm}$ \\
Saturday & $14: 00 / 02: 00 \mathrm{pm}$ & $16 \mathrm{~h} 00 / 04: 00 \mathrm{pm}$ \\
& $20 \mathrm{~h} 00 / 08: 00 \mathrm{pm}$ & $22 \mathrm{~h} 00 / 10: 30 \mathrm{pm}$ \\
\hline
\end{tabular}


Table 2 - Descriptive Statistics

\begin{tabular}{lccccc}
\hline Statistic & $\mathbf{N}$ & Mean & St. Dev. & Min & Max \\
\hline Number of Passenger & $2,120,061$ & 1.688 & 1.343 & 1.000 & 6.000 \\
Trip Distance & $2,120,061$ & 2.873 & 2.888 & 0.200 & 19.400 \\
Fare Amount & $2,120,061$ & 12.365 & 8.359 & 3.500 & 52.000 \\
Tip Amount & $2,120,061$ & 2.471 & 1.912 & 0.000 & 17.400 \\
Total Amount & $2,120,061$ & 16.235 & 10.579 & 4.000 & 86.190 \\
To Theater District & $2,120,061$ & 0.068 & 0.251 & 0.000 & 1.000 \\
From Theater District & $2,120,061$ & 0.096 & 0.294 & 0.000 & 1.000 \\
From a Hotel & $2,120,061$ & 0.199 & 0.400 & 0.000 & 1.000 \\
To a Hotel & $2,120,061$ & 0.166 & 0.372 & 0.000 & 1.000 \\
Ave. Temperature & $2,120,061$ & 51.378 & 19.255 & 10.500 & 84.500 \\
Precipitation & $2,120,061$ & 0.137 & 0.384 & 0.000 & 4.970 \\
New Snow & $2,120,061$ & 0.155 & 0.873 & 0.000 & 11.000 \\
Snow Depth & $2,120,061$ & 1.651 & 3.808 & 0.000 & 19.000 \\
Last Minute & $2,120,061$ & 0.003 & 0.057 & 0.000 & 1.000 \\
From Top Hotel & $2,120,061$ & 0.016 & 0.124 & 0.000 & 1.000 \\
To Top Hotel & $2,120,061$ & 0.011 & 0.105 & 0.000 & 1.000 \\
Tip Percentage & $2,120,061$ & 0.151 & 0.048 & 0.000 & 0.769 \\
Tip Dummy & $2,120,061$ & 0.971 & 0.167 & 0.000 & 1.000 \\
From National & $1,646,593$ & 0.050 & 0.218 & 0.000 & 1.000 \\
To National & $1,646,593$ & 0.041 & 0.197 & 0.000 & 1.000 \\
From International & $1,646,593$ & 0.031 & 0.174 & 0.000 & 1.000 \\
To International & $1,646,593$ & 0.026 & 0.159 & 0.000 & 1.000 \\
\hline
\end{tabular}


Table 3 - OLS Results

\begin{tabular}{lllll}
\hline & \multicolumn{4}{c}{ Dependent Variable: Tip Percentage } \\
\cline { 2 - 5 } & $(1)$ & $(2)$ & $(3)$ & $(4)$ \\
\hline From Hotel & $0.089^{* * *}$ & $0.065^{* * *}$ & $0.065^{* * *}$ & $0.058^{* * *}$ \\
& $(0.009)$ & $(0.009)$ & $(0.009)$ & $(0.009)$ \\
To Hotel & $0.078^{* * *}$ & $0.050^{* * *}$ & $0.050^{* * *}$ & $0.049^{* * *}$ \\
& $(0.010)$ & $(0.010)$ & $(0.010)$ & $(0.010)$ \\
To Theater & $0.150^{* * *}$ & $0.154^{* * *}$ & $0.147^{* * *}$ & $0.154^{* * *}$ \\
& $(0.015)$ & $(0.016)$ & $(0.015)$ & $(0.016)$ \\
From Theater & $0.207^{* * *}$ & $0.195^{* * *}$ & $0.194^{* * *}$ & $0.195^{* * *}$ \\
& $(0.013)$ & $(0.013)$ & $(0.013)$ & $(0.013)$ \\
From Hotel*To Theater & $0.278^{* * *}$ & $0.200^{* * *}$ & $0.199^{* * *}$ & $0.200^{* * *}$ \\
& $(0.032)$ & $(0.032)$ & $(0.032)$ & $(0.032)$ \\
To Hotel*From Theater & $0.281^{* * *}$ & $0.227^{* * *}$ & $0.226^{* * *}$ & $0.226^{* * *}$ \\
& $(0.030)$ & $(0.030)$ & $(0.030)$ & $(0.030)$ \\
To Top Hotel & & & & 0.021 \\
& & & & $(0.032)$ \\
From Top Hotel & & & & $0.086^{* * *}$ \\
& & & & $(0.028)$ \\
\hline Cab Controls & No & Yes & Yes & Yes \\
Weather Controls & No & No & Yes & Yes \\
\hline Observations & $2,120,061$ & $2,120,061$ & $2,120,061$ & $2,120,061$ \\
$\mathrm{R}^{2}$ & 0.001 & 0.003 & 0.003 & 0.003 \\
Adjusted R $\mathrm{R}^{2}$ & 0.001 & 0.003 & 0.003 & 0.003 \\
\hline
\end{tabular}

Note: $* \mathrm{p}<0.1 ; * * \mathrm{p}<0.05 ; * * * \mathrm{p}<0.01$; Cab controls: Trip Distance, Number of Passengers and Last Minute; Weather controls: Ave. Temperature, Precipitation, New Snow and Snow Depth. Top Hotels are those with four or five stars. 
Table 4 - Tobit Results

\begin{tabular}{|c|c|c|c|c|}
\hline & \multicolumn{4}{|c|}{ Dependent Variable: Tip Percentage } \\
\hline & (1) & (2) & (3) & (4) \\
\hline From Hotel & $\begin{array}{l}0.093 * * * \\
(0.009)\end{array}$ & $\begin{array}{l}0.068 * * * \\
(0.009)\end{array}$ & $\begin{array}{l}0.068 * * * \\
(0.009)\end{array}$ & $\begin{array}{l}0.061 * * * \\
(0.009)\end{array}$ \\
\hline To Hotel & $\begin{array}{l}0.079 * * * \\
(0.010)\end{array}$ & $\begin{array}{l}0.050^{* * *} \\
(0.010)\end{array}$ & $\begin{array}{l}0.050^{* * *} \\
(0.010)\end{array}$ & $\begin{array}{l}0.050^{* * *} \\
(0.010)\end{array}$ \\
\hline To Theater & $\begin{array}{l}0.135 * * * \\
(0.015)\end{array}$ & $\begin{array}{l}0.139 * * * \\
(0.015)\end{array}$ & $\begin{array}{l}0.132^{* * *} \\
(0.015)\end{array}$ & $\begin{array}{l}0.140^{* * *} \\
(0.015)\end{array}$ \\
\hline From Theater & $\begin{array}{l}0.206^{* * *} \\
(0.013)\end{array}$ & $\begin{array}{l}0.193^{* * *} \\
(0.013)\end{array}$ & $\begin{array}{l}0.192^{* * *} \\
(0.013)\end{array}$ & $\begin{array}{l}0.194^{* * *} \\
(0.013)\end{array}$ \\
\hline From Hotel*To Theater & $\begin{array}{l}0.270^{* * *} \\
(0.030)\end{array}$ & $\begin{array}{l}0.191^{* * *} \\
(0.030)\end{array}$ & $\begin{array}{l}0.190 * * * \\
(0.030)\end{array}$ & $\begin{array}{l}0.190^{* * *} \\
(0.030)\end{array}$ \\
\hline To Hotel*From Theater & $\begin{array}{l}0.274 * * * \\
(0.029)\end{array}$ & $\begin{array}{l}0.218^{* * *} \\
(0.029)\end{array}$ & $\begin{array}{l}0.217 * * * \\
(0.029)\end{array}$ & $\begin{array}{l}0.218^{* * *} \\
(0.029)\end{array}$ \\
\hline To Top Hotel & & & & $\begin{array}{l}0.020 \\
(0.033)\end{array}$ \\
\hline From Top Hotel & & & & $\begin{array}{l}0.085^{* * *} \\
(0.031)\end{array}$ \\
\hline logSigma & $\begin{array}{l}1.603^{* * *} \\
(0.0003)\end{array}$ & $\begin{array}{l}1.602 * * * \\
(0.0003)\end{array}$ & $\begin{array}{l}1.602 * * * \\
(0.0003)\end{array}$ & $\begin{array}{l}1.602^{* * *} \\
(0.0003)\end{array}$ \\
\hline $\begin{array}{l}\text { Cab Controls } \\
\text { Weather Controls }\end{array}$ & $\begin{array}{l}\text { No } \\
\text { No }\end{array}$ & $\begin{array}{l}\text { Yes } \\
\text { No }\end{array}$ & $\begin{array}{l}\text { Yes } \\
\text { Yes }\end{array}$ & $\begin{array}{l}\text { Yes } \\
\text { Yes }\end{array}$ \\
\hline Observations & $2,120,061$ & $2,120,061$ & $2,120,061$ & $2,120,061$ \\
\hline Log Likelihood & $-6,326,800$ & $-6,324,090$ & $-6,323,941$ & $-6,323,933$ \\
\hline Akaike Inf. Crit. & $12,653,616$ & $12,648,201$ & $12,647,909$ & $12,647,900$ \\
\hline Bayesian Inf. Crit. & $12,653,717$ & $12,648,339$ & $12,648,085$ & $12,648,114$ \\
\hline
\end{tabular}

Note: $* \mathrm{p}<0.1 ; * * \mathrm{p}<0.05 ; * * * \mathrm{p}<0.01$; Cab controls: Trip Distance, Number of Passengers and Last Minute; Weather controls: Ave. Temperature, Precipitation, New Snow and Snow Depth. Top Hotels are those with four or five stars. 
Table 5 - Heckit Results

\begin{tabular}{|c|c|c|c|c|}
\hline & \multicolumn{4}{|c|}{ Dependent Variable: Tip Percentage } \\
\hline & (1) & $(2)$ & (3) & (4) \\
\hline From Hotel & $\begin{array}{l}0.053^{* * *} \\
(0.008)\end{array}$ & $\begin{array}{l}0.035^{* * *} \\
(0.008)\end{array}$ & $\begin{array}{l}0.035^{* * *} \\
(0.008)\end{array}$ & $\begin{array}{l}0.027 * * * \\
(0.008)\end{array}$ \\
\hline To Hotel & $\begin{array}{l}0.070^{* * *} \\
(0.008)\end{array}$ & $\begin{array}{l}0.049 * * * \\
(0.008)\end{array}$ & $\begin{array}{l}0.050^{* * *} \\
(0.008)\end{array}$ & $\begin{array}{l}0.048 * * * \\
(0.009)\end{array}$ \\
\hline To Theater & $\begin{array}{l}0.331^{* * *} \\
(0.013)\end{array}$ & $\begin{array}{l}0.328 * * * \\
(0.014)\end{array}$ & $\begin{array}{l}0.328 * * * \\
(0.013)\end{array}$ & $\begin{array}{l}0.328^{* * *} \\
(0.014)\end{array}$ \\
\hline From Theater & $\begin{array}{l}0.229 * * * \\
(0.011)\end{array}$ & $\begin{array}{l}0.220 * * * \\
(0.011)\end{array}$ & $\begin{array}{l}0.219 * * * \\
(0.011)\end{array}$ & $\begin{array}{l}0.221 * * * \\
(0.011)\end{array}$ \\
\hline From Hotel*To Theater & $\begin{array}{l}0.388 * * * \\
(0.028)\end{array}$ & $\begin{array}{l}0.332 * * * \\
(0.028)\end{array}$ & $\begin{array}{l}0.331^{* * *} \\
(0.028)\end{array}$ & $\begin{array}{l}0.331 * * * \\
(0.028)\end{array}$ \\
\hline To Hotel*From Theater & $\begin{array}{l}0.380 * * * \\
(0.026)\end{array}$ & $\begin{array}{l}0.342^{* * *} \\
(0.026)\end{array}$ & $\begin{array}{l}0.341^{* * *} \\
(0.026)\end{array}$ & $\begin{array}{l}0.341 * * * \\
(0.026)\end{array}$ \\
\hline To Top Hotel & & & & $\begin{array}{l}0.025 \\
(0.028)\end{array}$ \\
\hline From Top Hotel & & & & $\begin{array}{l}0.100^{* * *} \\
(0.024)\end{array}$ \\
\hline Cab Controls & No & Yes & Yes & Yes \\
\hline Weather Controls & No & No & Yes & Yes \\
\hline Observations & $2,120,061$ & $2,120,061$ & $2,120,061$ & $2,120,061$ \\
\hline Log Likelihood & $-6,122,070$ & $-6,120,302$ & $-6,120,112$ & $-6,120,103$ \\
\hline \multirow[t]{2}{*}{$\rho$} & $\begin{array}{l}-0.027 \\
(0.018)\end{array}$ & $\begin{array}{l}-0.026 \\
(0.018)\end{array}$ & $\begin{array}{l}-0.027 \\
(0.018)\end{array}$ & $\begin{array}{l}-0.027 \\
(0.018)\end{array}$ \\
\hline & \multicolumn{4}{|c|}{ Selection Equation } \\
\hline Number of Passenger & $\begin{array}{l}-0.031^{* * *} \\
(0.003)\end{array}$ & $\begin{array}{l}-0.031 * * * \\
(0.003)\end{array}$ & $\begin{array}{l}-0.031 * * * \\
(0.003)\end{array}$ & $\begin{array}{l}-0.031^{* * *} \\
(0.003)\end{array}$ \\
\hline Precipitation & $-0.011 *$ & $-0.011 *$ & $-0.011 *$ & $-0.011 *$ \\
\hline Constant & $\begin{array}{l}(0.005) \\
1.958 * * * \\
(0.003)\end{array}$ & $\begin{array}{l}(0.005) \\
1.958 * * * \\
(0.003)\end{array}$ & $\begin{array}{l}(0.005) \\
1.958 * * * \\
(0.003)\end{array}$ & $\begin{array}{l}(0.005) \\
1.958 * * * \\
(0.003)\end{array}$ \\
\hline
\end{tabular}

Note: $* \mathrm{p}<0.1 ; * * \mathrm{p}<0.05 ; * * * \mathrm{p}<0.01$; Cab controls: Trip Distance and Last Minute; Weather controls: Ave. Temperature, New Snow and Snow Depth. Top Hotels are those with four or five stars. 
Table 6 - Falsification Results

\begin{tabular}{|c|c|c|c|}
\hline & \multicolumn{3}{|c|}{ Dependent Variable: Tip Percentage } \\
\hline & OLS & Tobit & Heckit \\
\hline \multirow{2}{*}{ From Hotel $(\mathrm{t}<0.05)$} & $0.058 * * *$ & $0.061 * * *$ & $0.027 * * *$ \\
\hline & $(0.009)$ & $(0.009)$ & $(0.008)$ \\
\hline \multirow{2}{*}{ To Hotel $(\mathrm{t}<0.05)$} & $0.049 * * *$ & $0.050 * * *$ & $0.048 * * *$ \\
\hline & $(0.010)$ & $(0.010)$ & $(0.009)$ \\
\hline \multirow[t]{2}{*}{ To Theater } & $0.154^{* * *}$ & $0.140 * * *$ & $0.328 * * *$ \\
\hline & $(0.016)$ & $(0.015)$ & $(0.014)$ \\
\hline \multirow{2}{*}{ From Theater } & $0.195^{* * *}$ & $0.194 * * *$ & $0.221^{* * *}$ \\
\hline & $(0.013)$ & $(0.013)$ & $(0.011)$ \\
\hline \multirow[t]{2}{*}{ From Hotel*To Theater $(\mathrm{t}<0.05)$} & $0.200 * * *$ & $0.190 * * *$ & $0.331^{* * *}$ \\
\hline & $(0.032)$ & $(0.030)$ & $(0.028)$ \\
\hline \multirow[t]{2}{*}{ To Hotel*From Theater $(\mathrm{t}<0.05)$} & $0.226 * * *$ & $0.218 * * *$ & $0.341^{* * *}$ \\
\hline & $(0.030)$ & $(0.029)$ & $(0.026)$ \\
\hline \multirow[t]{2}{*}{ From Hotel $(\mathrm{t}>0.05 \& \mathrm{t}<0.10)$} & -0.248 & -0.272 & 0.007 \\
\hline & $(0.274)$ & $(0.268)$ & $(0.240)$ \\
\hline \multirow[t]{2}{*}{ To Hotel $(\mathrm{t}>0.05 \& \mathrm{t}<0.10)$} & $0.581 * *$ & $0.587 * *$ & $0.548 * *$ \\
\hline & $(0.294)$ & $(0.267)$ & $(0.255)$ \\
\hline \multirow[t]{2}{*}{ From Hotel*To Theater $(\mathrm{t}>0.05 \& \mathrm{t}<0.10)$} & 0.577 & 0.654 & -0.285 \\
\hline & $(1.023)$ & $(1.060)$ & $(0.878)$ \\
\hline \multirow[t]{2}{*}{ To Hotel*From Theater $(\mathrm{t}>0.05 \& \mathrm{t}<0.10)$} & -0.528 & -0.560 & -0.193 \\
\hline & $(1.094)$ & $(1.005)$ & $(0.959)$ \\
\hline Cab Controls & Yes & Yes & Yes \\
\hline Weather Controls & Yes & Yes & Yes \\
\hline Observations & $2,120,061$ & $2,120,061$ & $2,120,061$ \\
\hline Log Likelihood & & $-6,323,391$ & $-6,120,100$ \\
\hline $\mathrm{R}^{2}$ & 0.003 & & \\
\hline
\end{tabular}


Table 7 - International vs. National Results

\begin{tabular}{|c|c|c|c|}
\hline & \multicolumn{3}{|c|}{ Dependent Variable: Tip Percentage } \\
\hline & OLS & Tobit & Heckit \\
\hline \multirow[t]{2}{*}{ To Theater } & $0.133 * * *$ & $0.121^{* * *}$ & $0.289 * * *$ \\
\hline & $(0.018)$ & $(0.018)$ & $(0.016)$ \\
\hline \multirow[t]{2}{*}{ From Theater } & $0.194 * * *$ & $0.193 * * *$ & $0.205^{* * *}$ \\
\hline & $(0.015)$ & $(0.015)$ & $(0.013)$ \\
\hline \multirow[t]{2}{*}{ From National } & -0.005 & -0.003 & $-0.033 * *$ \\
\hline & $(0.019)$ & $(0.019)$ & $(0.016)$ \\
\hline \multirow[t]{2}{*}{ To National } & $0.101^{* * *}$ & $0.102 * * *$ & $0.092 * * *$ \\
\hline & $(0.021)$ & $(0.021)$ & $(0.018)$ \\
\hline \multirow[t]{2}{*}{ From National*To Theater } & $0.283 * * *$ & $0.274 * * *$ & $0.416^{* * *}$ \\
\hline & $(0.069)$ & $(0.065)$ & $(0.060)$ \\
\hline \multirow[t]{2}{*}{ To National *From Theater } & $0.165^{* *}$ & $0.154 * *$ & $0.309 * * *$ \\
\hline & $(0.066)$ & $(0.064)$ & $(0.058)$ \\
\hline \multirow[t]{2}{*}{ From International } & $0.073 * * *$ & $0.076 * * *$ & $0.046 * *$ \\
\hline & $(0.023)$ & $(0.024)$ & $(0.020)$ \\
\hline \multirow[t]{2}{*}{ To International } & $-0.074 * * *$ & $-0.074 * * *$ & $-0.072 * * *$ \\
\hline & $(0.025)$ & $(0.026)$ & $(0.022)$ \\
\hline \multirow[t]{2}{*}{ From International*To Theater } & $0.359 * * *$ & $0.353^{* * *}$ & $0.459 * * *$ \\
\hline & $(0.091)$ & $(0.086)$ & $(0.079)$ \\
\hline \multirow[t]{2}{*}{ To International *From Theater } & $0.234 * * *$ & $0.230 * * *$ & $0.300 * * *$ \\
\hline & $(0.086)$ & $(0.083)$ & $(0.075)$ \\
\hline Cab Controls & Yes & Yes & Yes \\
\hline Weather Controls & Yes & Yes & Yes \\
\hline Observations & $1,646,593$ & $1,646,593$ & $1,646,593$ \\
\hline Log Likelihood & & $-4,910,704$ & $-4,752,800$ \\
\hline $\mathrm{R}^{2}$ & 0.003 & & \\
\hline
\end{tabular}


Appendix 1 - Description and Source of Variables

\begin{tabular}{|c|c|c|}
\hline Variable & Description & Source \\
\hline Number of Passenger & Number of passengers in trip & TLC \\
\hline Trip Distance & Total trip distance & TLC \\
\hline Pickup Longitude & Pick-up longitude for trip & TLC \\
\hline Pickup Latitude & Pick-up latitude for trip & TLC \\
\hline Dropoff Longitude & Drop-off longitude for trip & TLC \\
\hline Dropoff Latitude & Drop-off latitude for trip & TLC \\
\hline Fare Amount & Trip fare amount & TLC \\
\hline Tip Amount & Tip amount paid & TLC \\
\hline Total Amount & Total amount paid & TLC \\
\hline To Theater District & Binary variable, equals 1 if drop-off location is theater district & TLC \Broadway \\
\hline From Theater District & Binary variable, equals 1 if pick-up location is theater district & TLC \Broadway \\
\hline From a Hotel & Binary variable, equals 1 if pick-up location is 0.05 miles from hotel & TLC \Hotel \\
\hline To a Hotel & Binary variable, equals 1 if drop-off location is 0.05 miles from hotel & TLC \Hotel \\
\hline From Top Hotel & Binary variable, equals 1 if pick-up location is four or five star hotel & TLC \Forbes \\
\hline To Top Hotel & Binary variable, equals 1 if drop-off location is four or five star hotel & TLC \Forbes \\
\hline Max Temperature & Daily maximum temperature in Fahrenheit & NOAA \\
\hline Min Temperature & Daily minimum temperature in Fahrenheit & NOAA \\
\hline Avg. Temperature & Daily average temperature in Fahrenheit & NOAA \\
\hline Precipitation & Daily precipitation in inches & NOAA \\
\hline New Snow & Daily snowfall in inches & NOAA \\
\hline Snow Depth & $\begin{array}{l}\text { Daily snow depth in inches } \\
\text { Binary variable, equals } 1 \text { if drop-off time is } 5 \text { min before or after }\end{array}$ & NOAA \\
\hline Last Minute & show & Taxi Data\Broadway \\
\hline Tip Percentage & Percentage of tip from total amount paid & TLC \\
\hline Tip Dummy & Binary variable, equals 1 if there is a tip & TLC \\
\hline
\end{tabular}

